\title{
Under new management
}

\author{
After decades of rule by first the military and then parties associated with \\ the privileged élite, Brazil now has a left-wing president. David Adam \\ considers the implications for the country's science.
}

f few Brazilian scientists were aware of Roberto Amaral when he took up office as the country's minister of science and technology on 2 January, most knew his name a week later. In his maiden media interview, Amaral seemed to suggest that Brazil was about to resurrect its nuclearweapons programme - a gaffe that forced officials to issue a hasty statement ruling out such a volatile move.

It was an explosive start that played up to the worst fears of some researchers about the new government. Amaral, a political scientist and journalist who is vice-president of the Brazilian Socialist Party, was given control over research in the horse-trading that followed Brazil's election last year of its first left-wing government in four decades. President Luiz Inácio Lula da Silva, known popularly as Lula, was elected to bring about a social revolution, and the country's scientists were unsure about which way the coming winds of change would blow them.

Scientists weren't the only ones to express concern - economists and business leaders were also worried about what the new government had in store. But some six months after the new administration took over in January, there is a widespread mood of cautious optimism. Lula's government has won plaudits for its generally prudent management of Brazil's shaky economy. Scientists, meanwhile, have been wooed with a pledge to double federal spending on research within his four-year term, and to boost the number of young researchers being trained.

Controversially, however, Lula's government also wants to widen the geographical spread of Brazil's research base, currently dominated by the southern states of Rio de Janeiro and São Paulo - a move that is bound to create tensions between the current haves and have-nots of Brazilian science. The administration also faces a crunch over genetically modified (GM) crops: a court of appeal is expected to rule soon on whether the previous government's decision to license the commercial planting of GM soya is illegal, as consumer and green activists successfully argued in a lower court.

Brazil's scientists have learned to treat announcements about future riches with scepticism - too many government pledges have gone unfulfilled in the past. But for now

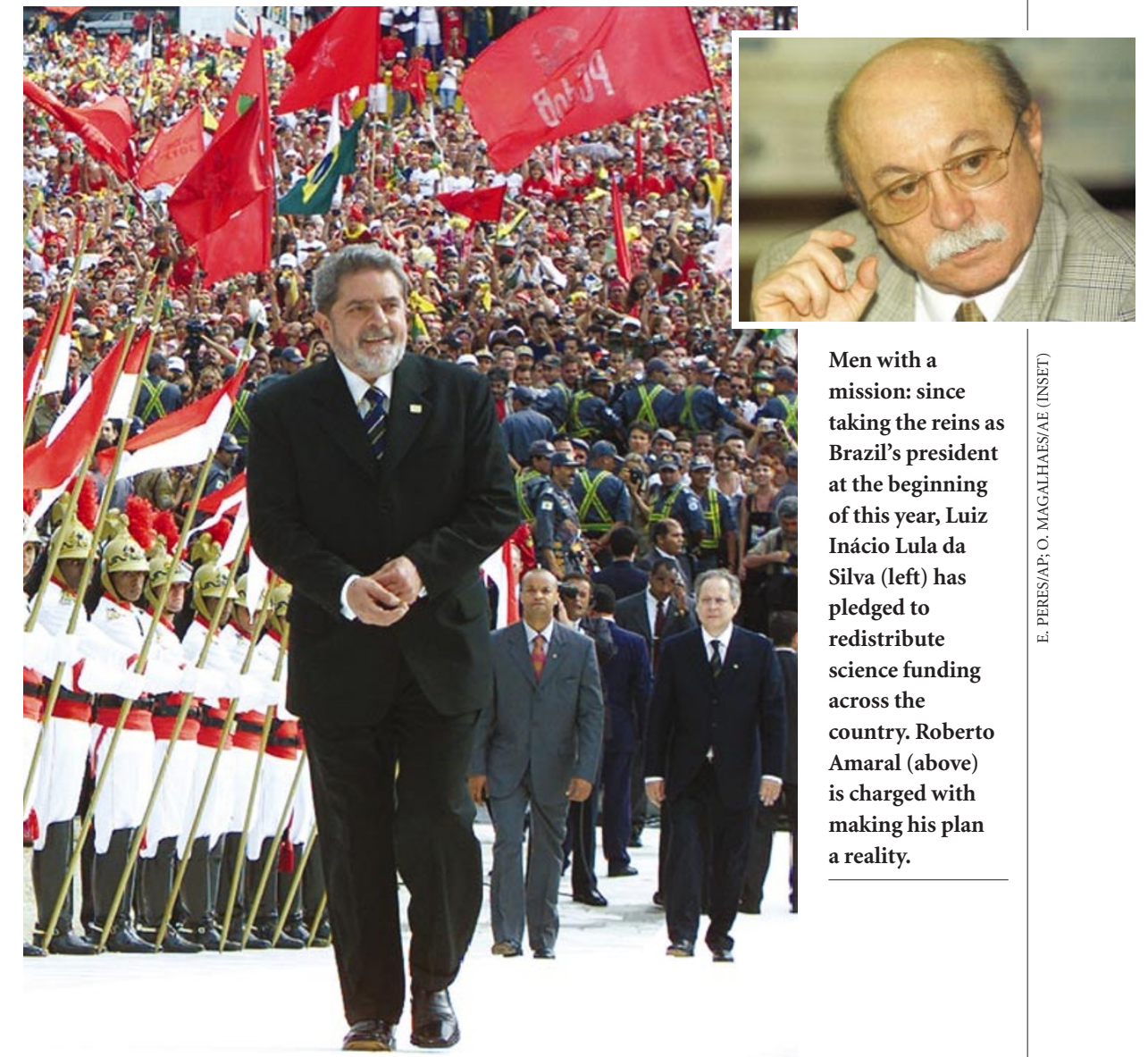

at least, the signs are promising. The US\$500-million annual federal research budget was largely spared from a series of stringent cuts, intended to help reduce Brazil's internal and international debts, announced shortly after Lula took office. "The new government has a very good dialogue with the scientific community," says Glaci Zancan, a biologist at the Federal University of Paraná and president of the Brazilian Society for the Advancement of Science.

\section{Fruits of labour}

Brazilian science has already proved that it can compete on the international stage, with the publication in 2000 of the complete genome sequence of the citrus pathogen Xylella fastidiosa (A. J. G. Simpson et al. Nature 406, 151-157; 2000) by a consortium in the state of São Paulo. But despite such pockets of excellence, the quality of science in this enormous country remains mixed. In terms of the number of papers published in international journals, Brazil ranks 17th in the world, contributing just $1.3 \%$ of the total. "That level of performance is, quite frankly, inadequate," says Amaral. "But our position in applied science and technology is even worse." Based on patents filed, Brazil is a woeful 43rd in the world. "While South Korea registered 3,472 only managed 113," laments Amaral.

Brazil's leading researchers agree that their country's science will be most competitive if it focuses on issues that are of key domestic importance. With more than half of Brazil's territory taken up by the patents in the United States in 2002, we 
